\title{
Regional Trade Agreements and its Perspectives for Small Open Economies
}

\section{Tamta Mikaberidze*}

\section{ARTICLE INFO \\ Article history: \\ Accepted: October 152020. \\ Approved: December 152020. \\ Keywords: \\ Regional Trade, Economic Integration, Export similar- ity, Georgia -CIS trade.}

\section{A B S T R A C T}

Studying foreign trade issues and developing the right strategy plays a key role in reviving the country's economy. Generally, the countries are involved in these processes, both at the international and regional levels. The growth of both bilateral and multilateral regional trade agreements (RTA) includes the agreements between the countries at significantly different stages of development. To reveal these differences, RTA generally contains specific and different types of provisions aiming the benefits for less developed partners. At the same time, such agreements make it possible to select a partner from a political and strategic point of view. The article discusses the importance and perspectives of regional trade through the prism of liberalization and historical experience, on Georgia - CIS example. Current trade flows with major partner countries are analyzed and the opportunities for diversity trade with other CIS trading partners are highlighted based on the intra-industry trade Index and the Finger-Kreinin Index. This analysis allows us to implement practical measures to increase the efficiency of external economic flows by identifying still unused reserves.

(C) 2020 Published by the Institute for Development Studies, Sulkhan-Saba Orbeliani University.

\section{Introduction}

Institutional, regional and national initiatives have laid the ground for many regional free trade agreements, customs unions, and regional cooperation activities around the world, also the specialized bilateral agreements to solve such issues as investments, export credit, double taxation, and more.
The level of well-being of the population greatly depends on the country's involvement in international trade and the degree to which it realizes its potential. Therefore, studying foreign trade issues and developing the right strategy plays a key role in reviving the country's economy. Generally, the countries are involved in these processes, both at the international and regional levels. The growth of both bilateral and multilateral regional trade agreements (RTA) includes the

\footnotetext{
* Doctor of Economics, Institute for Development Studies, Sulkhan-Saba Orbeliani University, Tbilisi, Geor-
} gia. 
agreements between the countries at significantly different stages of development. To reveal these differences, RTA generally contains specific and different types of provisions aiming the benefits for less developed partners. At the same time, such agreements make it possible to select a partner from a political and strategic point of view.

The theoretical framework was developed based on the knowledge and analysis of various authors and studies of international organizations (Xinpeng \& Ligang, 2000; Dyker et al., 2008; Kreinin, Plummer, 2000; Heydon, 2003, etc., Global Economic Prospects 2005).

Various aspects of the issue are discussed by the author in previous publications (Mikaberidze, 2015, 2016, 2017).

This papework aims to discuss the importance and perspectives of regional trade through the prism of liberalization and historical experience, on Georgia - CIS example. Current trade flows with major partner countries are analyzed and the opportunities for diversity trade with other CIS trading partners are highlighted based on the intra-industry trade Index and the Finger-Kreinin Index. This analysis allows us to implement practical measures to increase the efficiency of external economic flows by identifying still unused reserves.

\section{Research methods}

The research period covers the years 2010-1015. On the one hand, Georgia's export in the world and, on the other hand, the export of CIS countries (being Georgia's partners) in the world were analyzed for the mentioned period. 30 largest exported commodity items were revealed within this period.

Taken as the research basis was the data of the National Statistics Office of Georgia and UN Comtrade's international trade statistics data at the level of SITC three-digit classifier.
A study on the similarity of Georgia's exports to CIS member states has been conducted. In order to establish the main directions of trade structure improvement, we have measured the similarity of the trade and industrial structures of Georgia and its CIS trade partners. The study is based on the index of export similarities or GL (Grubel-Lloyd) Index (determining the intra-industry trade value) (Grubel \& Lloyd, 1975). On the other hand, we calculated the index of export similarities - the Finger-Kreinin Index (offered by J. Finger and M. Kreinin, 1979). The dynamics of the indices are given in chronological order and the results are presented in the form of diagrams.

The paperwork presents an economic analysis of the results obtained, which includes the general methodological foundations of analysis and synthesis, abstraction, induction-deduction, and dialectics. The perspectives of the foreign trade policy of Georgia and its partner $\mathrm{CIS}$ member states in the prism of similarity of intra-industry trade and exports are assessed.

\section{Regionalism and Developing Countries}

It should be noted that the provisions of regional trade agreements often go beyond the provisions of the World Trade Organization (WTO). Although the regional agreements complete a multilateral trading system, they cannot replace them. The scale of regionalism has grown sharply in recent years as the developing countries become interested in deep integration through institutional strengthening, which is also the subject of our interest.

From a regional point of view, Georgia's participation in the free trade zone within the Commonwealth of Independent States is noteworthy, within the Black Sea Economic Cooperation (BSEC) and Democracy and Economic Development Organization - GUAM Free Trade Zone, as the markets of Turkey 
and the CIS are very convenient for Georgian exports, because the Georgian products are more or less adapted to their markets, both in terms of their quality requirements and competitiveness.

For any small open economies, it is important to diversify markets and thus to develop the integration links in different directions. One such direction for us is the postSoviet space. The catastrophic consequences after the breaking-up the traditional business-economic relations after the collapse of the Soviet Union, the complete collapse of the attempt to enter the world market, made clear the need for the country to re-establish economic ties with post-Soviet countries. And the opportunity to develop specialization is the main driving force for getting the benefits from economic ties and free trade.

Today, Georgia has a comparative advantage over the post-Soviet countries in the production of many goods, on which it specialized during the Soviet era. Thus, by strengthening trade and economic ties in the post-Soviet space, the country will be able to get the benefits from the positive results from the development of industrial specialization. There are important preconditions for deepening integration in the post-Soviet space: unified transport, energy, communications systems are still maintained; unified standards, technical requirements, and sanitary norms; technological and territorial proximity; mutual market knowledge; having some trust in each other's products; the existence of cooperative connections between enterprises, etc.

To prove this, consider the statistics: despite the implementation of the policy of liberalization, accession to the World Trade Organization (since 2000) and the recent signing of the Deep and Comprehensive Free Trade Agreement (DCFTA) with the European Union, In 2019 Georgia's trade turnover with the CIS increased by $18 \%$ to 4.439 .4 million USD and the total trade balance is $34,6 \%$. The export is increased by $20 \%$ and amounted to 2 003.1 million USD (re-export $57 \%$ ) and it accounted for $53.1 \%$ of the country's total exports. The import was decreased by $9.5 \%$, amounted to 436.3 million USD and it accounted for $26.9 \%$ of the country's total imports. The largest export flows come from commodities such as agricultural products (including wine, mineral water, spirits, nuts, turmeric, spices, tobacco products, citrus, cattle), industrial products (including cars, medicinal, nitrogen fertilizers, trucks, cyanides, and oxycyanides, carbon steel rods, ferroalloys, pharmaceutical products, tobacco products, etc.).

As for Georgia's largest trading partners, whose share in total trade turnover is up to $70 \%$ are Turkey, Russia, China, Azerbaijan, Armenia, Ukraine, USA, Germany, Bulgaria, and Romania. Accordingly, 4 of the main trading partners are members of the CIS. With other countries in the post-Soviet space that are not major trading partners (Moldova, Belarus, Kyrgyzstan, etc.), there are prospects for increased trade flows and product diversification, which we discuss below (Fig. 1).

As it was said above though the regional agreements complete the multilateral trade systems, they can't replace them (Heydon, 2003). The same can be said concerning the asymmetric regional provisions. Regional agreements may work faster in certain areas than multilateral agreements, but they can't replace the latter with regard to non-discriminatory (preferential promotion) liberalization and the elaboration of multilateral extensive rules.

The preferential regional trade agreements offer faster access to the market than it is possible during the multilateral negotiation process. This may become an important factor for the business as the product cycle is shorter than the multilateral negotiation cy- 
cle, this factor is highlighted in the Doha Development Agenda as an impediment to progress.

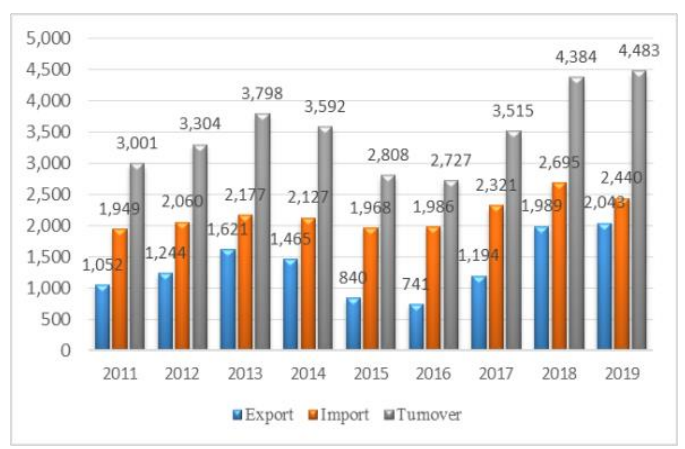

Fig. 1. Georgia-CIS Foreign Trade Dynamics (million USD).

Even if we assume that relatively less developed countries will be able to see more profit by entering into regional relations in terms of asymmetry, this profit should be compared to the costs incurred by a member country to join the preferential agreements. It is well known that most of these costs are due to the increasing difficulties faced by businesses in their relations with member countries, where no less space is occupied by the growing rules of product's origin and standardization. Signing a growing number of contracts and agreements gives us a lot of rules about the origin of the product since multilateral relationships typically involve individual negotiations with a member country, require a lot of detail and mechanism analysis. This is the balance that must be taken into account when moving to asymmetric integration.

Georgia participates in the Multilateral Agreement on the Establishment of a Free Trade Area in the CIS space (April 15, 1994), which provides free trade between the member states. This Agreement has been ratified by all parties except the Russian Federation. In addition, Georgia has signed a "bilateral free trade agreement" with eight CIS member states, only six of them are in force, they also provide the exemption from customs duties the trade with goods and services. These countries are Azerbaijan, Armenia, Russia, Turkey, Kazakhstan, and Ukraine.

\section{Georgia's Export Flows Diversification Is- sues}

In order to assess better the involvement and role of the partnership in foreign trade with the countries of the post-Soviet space, to examine better the results and prospects of the partnership, we analyzed the structural similarity of Georgia with the export structure of the partner countries. For this purpose, we conducted a survey and calculated Georgia's intra-industry trade index - the same as the Grubel-Lloyd index in relation to the CIS countries according to the SITC classifier at three-digit, as well as the export similarity Finger-Kreinin (FK) index according to 30 largest export goods with partner countries.

After the liberalization of trade policy, as well as the liberalization of capital and labor force in Georgia, it is possible to develop the trade infrastructure with integrative dynamism, but it is also important to discuss the opportunities derived from deep integration. Tariff liberalization can significantly increase the level of welfare. The more similar and approximate economic policies have the countries, the more benefits they will receive as a result of the partnership. Similarities and approximations mean the removal of existing barriers as well as the development of a unified policy that will facilitate the development of trade between the partner countries, make the investments, creating positive external factors, and increasing productivity (Dyker et al., 2008).

Intra-Industry trade is a key indicator of the potential for deep integration between partner countries. There are two types of intra-industry trade: 1 . Interchange of similar 
goods of approximately the same quality and price; 2 . Interchange of similar goods, but different quality and price; Exchange of goods within the trade classification is a vertically integrated supply network (parts of finished products and partially finished products). Each of them in the process of economic integration makes it possible to capture the niche of specialization, which will help to increase productivity.

The highest intra-industry trade index was revealed with Belarus (99\%), which is in 37 th place among the trade partners of Georgia according to its turnover, with Moldova $(78 \%)$ - in 49th place. However, it should be noted that over the years, trade turnover with these countries has been steadily increasing. Quite a high rate has been also observed over the years with Armenia, Kazakhstan, Azerbaijan (Fig. 2).

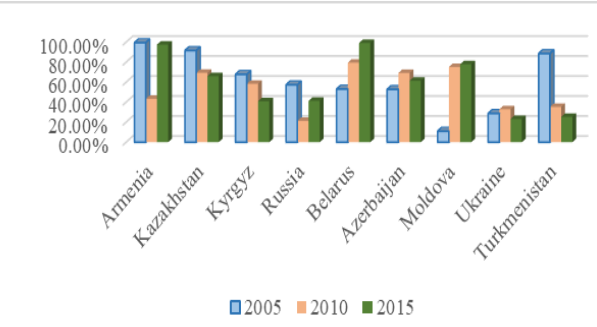

Fig. 2. Georgia's GL index with partner countries.

This shows that despite the size and proximity of the CIS countries' markets, Georgia's exports in this direction are much lower than possible. While the index survey by specific commodity flows it was revealed a high rate of indexation according to the specific commodity codes (Annex), which allows us to think about expanding and perfecting the nomenclature of export goods under these commodity codes for the future.

We have measured the quality of trade and industrial structure between Georgia and its trade partners according to the export similarity index proposed by J. Finger and $M$. Kreinin (1979). As it is known, in case if the index has been increasing during the time it means the approximation of the export structure of two countries that also indicates high ongoing competition between these two countries in the third country market (Pomfret, 1981; Pearson, 1994). On the other hand, the decrease in indexes indicates that the specialization of the two countries is growing in the third country market.

The FC index, which determines the similarity of exports with Georgia and its main trading partners, is quite low. However, the highest similarity rate among the countries under consideration is observed with Armenia (43.4\%) - which is lower than in 2010 (48.4\%). Small increases from 2010 to 2015 were observed only in the indexes of Ukraine, Russia, Moldova, and Belarus. This gives us the reason to think that there are opportunities for future cooperation with these countries, especially based on identified trends in intra-industry trade (Fig. 3).

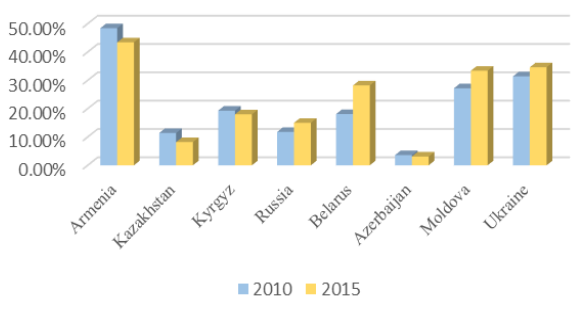

Fig. 3. Georgia's FK index with Partner countries.

\section{Conclusion}

In our opinion, the development of international flows should be promoted both regionally and globally. It is true that the European Union is a very important and oriented market for Georgia's exports, and its importance is increasing within the DCFTA, however, it is very important to raise regional aspects and one of them is the post-soviet space. Improving the quality of foreign trade and diversifying export commodity flows and markets, to our opinion, should be done by taking into account the trends set according 
to our calculations, in particular, goods of high quality within the intra-industry trade, such as agricultural products, textiles, and industrial products, pharmaceuticals and other industrial products. It should be noted that the index of intra-industry trade and, at the same time, the index of similarity of exports is higher with those countries that are not major trading partners. Consequently, it is possible to develop these markets wisely, including both the realization markets and the industrial cooperation.

The only guarantee of sustainable development is interdependence and cooperation. The level of well-being of the population greatly depends on the country's involvement in international trade and the degree to which it realizes its potential. The countries are involved in this process both internationally and regionally.

Successful development in the region largely depends on the political will, the national interests of the countries, and the selection of the appropriate approach and time to solve the problems positively. Promoting peace and security in the region and the peaceful settlement of existing conflicts are vitally important. Bilateral and multilateral economic cooperation and the implementation of important projects will substantially strengthen the regional security system. Regional cooperation within one specific community is an effective means for developing all participating countries. Taking into consideration the examples of other regions, the CIS countries need to work more closely together and strengthen economic ties. Encouraging regional cooperation, working together on every important issue, and addressing key issues will ultimately.

In our opinion, the development of international flows should be promoted both regionally and globally. This means that it is desirable to carry out the foreign trade with high-quality goods such as agriculture prod- ucts, textile, light industry products, pharmaceuticals, and others to take into account the trends established by the pre-calculations. This is evidenced by the fact that the index of intra-industry trade and the index of similarity of exports are even higher with those countries that are not major trading partners. However, no proportional change was observed between this index. Often its sudden increase or decrease is caused by a sudden change in trade flows from the smallest to the largest volume that is caused by nontrending trade flows and trade links between the countries (that is generally caused due to weak trade links, insufficient diversification of export-import structures).

The analysis also shows that with a number of countries in the CIS space we will be able to cooperate with the countries that have more or less similar export structures, namely: the possibility of medium and small volume cooperation. Though the countries with similar export structures are also our competitors in the world market, the volume of national export flows allows us to avoid conflicts of economic interests. However, we have a basis for cooperation in producing complementary goods and technologies.

\section{References}

Dyker, D., Emerson, M.,Gasiorek, M., Holmes, P., Jungmittag, A., Korchagin, V., Maliszewska, M., Kudina, A., Pertaia, G., Polyakov, E., Roudoi, A., Tokmazishvili, M. (2008). Economic Feasibility, General Economic Impact and Implications of a Free Trade Agreement Between the European Union and Georgia. CASE Network Reports, No. 79., 08.2008, Center for Social and Economic Research on behalf of CASE Network 12 Sienkiewicza, 00-010 Warsaw, Poland.

Finger, J. M., Kreinin, M. E. (1979). A Measure of 'Export Similarity' and Its Possible Uses, Economic Journal, 89. 


\section{JOURNAL OF DEVELOPMENT STUDIES}

Grubel, H., Lloyd, P.J. (1971). Intra-Industry Trade, the Theory and Measurement of International Trade in Differentiated Products. London: McMillan.

Heydon, K. (2008). Asymmetric integration: The role of regionalism. Developing countries and the WTO: Policy approaches, Samspon and Chambers (eds). United Nations University Press.

Heydon, K. (2003). Regionalism: A Complement, Not Substitute" . Regionalism and the Multilateral Trading System, 2003, Paris: OECD. pp.11-2.

Inventory of non-tariff provisions in Regional trade agreements. WTO, 5-May-1998, WT/REG/W/26.

Kreinin, M. E., Plummer, M. G. (2000). Economic Integration and Development: Has Regionalism Delivered for Developing Countries? Cheltenham, Edward Elgar.

Mikaberidze, T. (2017). The Role of Trade Technologies for Small Open Economics, Economics and Business. \#3 (IX). ISSN 1987-5789.

Mikaberidze, T. (2016). Intra-Industry Trade trends of Georgia, Georgian Economics, (Apr27) e-ISSN 1512-29278.

Mikaberidze, T. (2015). New Forms and
Trends of International Trade Amid the Global Crisis, In the proeedings: Strategica. Local versus Global. edited by Brătianu, C., Zbuchea, A., Pînzaru, F., Vătămănescu, E.-M. and Leon, R.D, Bucharest: Tritonic, ISBN 978-606-749-054-1, ISSN 2392-702X. http://strategica-conference.ro/previous-editions/2015-edition/.

Pearson, C.S. (1994). The Asian Export ladder, in the book edited by Shpu-Chin Yang, Manufactured Exports of East Asian Industrialising Economies: Possible Regional Cooperation, Armonk, NY: M.E Sharpe, 35-51.

Pomfret, R. (1981). The Impact of EEC enlargement on non-member Mediterranean countries' exports to EEC, Economic Journal, 91, 726-9.

Xinpeng, X., Ligang, S. (2000). Export Similarity and the pattern of east Asian development/ China in the Global Economy. Edward Elgar Cheltenham, UK. Northampton, MA, USA.

Global Economic Prospects 2005. Trade regionalism and Development. The World Bank. Wash., 2005,

Georgian National Statistics Office. Foreign Trade of Georgia. 2019. 
Georgia's Intra-Industry Trade (GL) Index with CIS at SITC three-digit level 2005-2015

\section{Annex}

\begin{tabular}{|c|c|c|c|c|c|}
\hline Country & SITC & Title & 2005 & 2010 & 2015 \\
\hline Russia & 001 & live animals other than animals of division 03 & 0,00 & 0,00 & 0,21 \\
\hline Armenia & 001 & live animals other than animals of division 03 & 0,37 & 0,18 & 0,19 \\
\hline Azerbaijan & 057 & $\begin{array}{l}\text { Fruit and nuts (not including oil nuts), fresh or } \\
\text { dried }\end{array}$ & 0,40 & 0,17 & 0,88 \\
\hline Moldovia & 057 & $\begin{array}{l}\text { Fruit and nuts (not including oil nuts), fresh or } \\
\text { dried }\end{array}$ & 0,00 & 0,21 & 0,59 \\
\hline Armenia & 057 & $\begin{array}{l}\text { Fruit and nuts (not including oil nuts), fresh or } \\
\text { dried }\end{array}$ & 0,07 & 0,01 & 0,83 \\
\hline Kirgizstan & 057 & $\begin{array}{l}\text { Fruit and nuts (not including oil nuts), fresh or } \\
\text { dried }\end{array}$ & 0,00 & 0,00 & 0,58 \\
\hline Belorussia & 058 & $\begin{array}{c}\text { Fruit, preserved, and fruit preparations (exclud- } \\
\text { ing fruit juices) }\end{array}$ & 0,00 & 0,99 & 0 \\
\hline Armenia & 058 & $\begin{array}{l}\text { Fruit, preserved, and fruit preparations (exclud- } \\
\text { ing fruit juices) }\end{array}$ & 0,00 & 0,26 & 0,07 \\
\hline Ukraine & 058 & $\begin{array}{l}\text { Fruit, preserved, and fruit preparations (exclud- } \\
\text { ing fruit juices) }\end{array}$ & 0,67 & 0,24 & 0,01 \\
\hline Azerbaijan & 081 & $\begin{array}{l}\text { Feeding stuff for animals (not including un- } \\
\text { milled cereals) }\end{array}$ & 0,00 & 0,67 & 0,63 \\
\hline Azerbaijan & 111 & Non-alcoholic beverages, n.e.s. & 0,00 & 0,04 & 0,13 \\
\hline Moldovia & 111 & Non-alcoholic beverages, n.e.s. & 0,00 & 0,60 & 0,42 \\
\hline Russia & 111 & Non-alcoholic beverages, n.e.s. & 0,00 & 0,00 & 0,12 \\
\hline Armenia & 111 & Non-alcoholic beverages, n.e.s. & 0,31 & 0,17 & 0,11 \\
\hline Ukraine & 111 & Non-alcoholic beverages, n.e.s. & 0,23 & 0,46 & 0,76 \\
\hline Azerbaijan & 112 & Alcoholic beverages & 0,12 & 0,17 & 0,47 \\
\hline Russia & 112 & Alcoholic beverages & 0,07 & 0,00 & 0,11 \\
\hline Armenia & 112 & Alcoholic beverages & 0,91 & 0,46 & 0,39 \\
\hline Ukraine & 112 & Alcoholic beverages & 0,32 & 0,30 & 0,48 \\
\hline
\end{tabular}


JOURNAL OF DEVELOPMENT STUDIES

\begin{tabular}{|c|c|c|c|c|c|}
\hline Azerbaijan & 248 & Cork and wood & 0,00 & 0,14 & 0 \\
\hline Armenia & 343 & Natural gas, whether or not liquefied & 0,00 & 0,00 & 0,91 \\
\hline Azerbaijan & 351 & Electric current & 0,00 & 0,83 & 0 \\
\hline Russia & 351 & Electric current & 0,00 & 0,72 & 0 \\
\hline $\begin{array}{l}\text { Kazakh- } \\
\text { stan }\end{array}$ & 523 & $\begin{array}{l}\text { Salts and peroxysalts, of inorganic acids and } \\
\text { metals }\end{array}$ & 0,12 & 0,15 & 0,05 \\
\hline Azerbaijan & 541 & $\begin{array}{l}\text { Medicinal and pharmaceutical products, other } \\
\text { than medicaments of group } 542\end{array}$ & 0,14 & 0,35 & 0,01 \\
\hline Armenia & 541 & $\begin{array}{l}\text { Medicinal and pharmaceutical products, other } \\
\text { than medicaments of group } 542\end{array}$ & 0,05 & 0,26 & 0,15 \\
\hline Ukraine & 541 & $\begin{array}{l}\text { Medicinal and pharmaceutical products, other } \\
\text { than medicaments of group } 542\end{array}$ & 0,46 & 0,30 & 0,38 \\
\hline Azerbaijan & 542 & $\begin{array}{l}\text { Medicaments (including veterinary medica- } \\
\text { ments) }\end{array}$ & 0,25 & 0,10 & 0,01 \\
\hline Belorussia & 542 & $\begin{array}{l}\text { Medicaments (including veterinary medica- } \\
\text { ments) }\end{array}$ & 0,01 & 0,09 & 0,37 \\
\hline Moldovia & 542 & $\begin{array}{l}\text { Medicaments (including veterinary medica- } \\
\text { ments) }\end{array}$ & 0,09 & 0,00 & 0,68 \\
\hline Armenia & 542 & $\begin{array}{l}\text { Medicaments (including veterinary medica- } \\
\text { ments) }\end{array}$ & 0,41 & 0,36 & 0,92 \\
\hline Ukraine & 542 & $\begin{array}{l}\text { Medicaments (including veterinary medica- } \\
\text { ments) }\end{array}$ & 0,03 & 0,11 & 0 \\
\hline $\begin{array}{l}\text { Kazakh- } \\
\text { stan }\end{array}$ & 542 & $\begin{array}{l}\text { Medicaments (including veterinary medica- } \\
\text { ments) }\end{array}$ & 0,33 & 0,98 & 0,02 \\
\hline Azerbaijan & 553 & $\begin{array}{l}\text { Perfumery, cosmetic or toilet preparations (ex- } \\
\text { cluding soaps) }\end{array}$ & 0,08 & 0,89 & 0,14 \\
\hline Azerbaijan & 625 & $\begin{array}{l}\text { Rubber tyres, interchangeable tyre treads, tyre } \\
\text { flaps and inner tubes for wheels of all kinds }\end{array}$ & 0,77 & 0,63 & 0 \\
\hline Armenia & 625 & $\begin{array}{l}\text { Rubber tyres, interchangeable tyre treads, tyre } \\
\text { flaps and inner tubes for wheels of all kinds }\end{array}$ & 0,61 & 0,02 & 0,89 \\
\hline
\end{tabular}


JOURNAL OF DEVELOPMENT STUDIES

\begin{tabular}{|c|c|c|c|c|c|}
\hline Russia & 671 & $\begin{array}{l}\text { Pig-iron, spiegeleisen, sponge iron, iron or steel } \\
\text { granules and powders and Ferro-alloys }\end{array}$ & 0,03 & 0,00 & 0,11 \\
\hline Azerbaijan & 676 & $\begin{array}{l}\text { Iron and steel bars, rods, angles, shapes and } \\
\text { sections (including sheet piling) }\end{array}$ & 0,19 & 0 & 0,13 \\
\hline Russia & 781 & $\begin{array}{l}\text { Motor cars and other motor vehicles principally } \\
\text { designed for the transport of persons (other } \\
\text { than motor vehicles for the transport of ten or } \\
\text { more persons, including the driver), including } \\
\text { station-wagons and racing cars. }\end{array}$ & 0,08 & 0,85 & 0,76 \\
\hline Ukraine & 781 & $\begin{array}{l}\text { Motor cars and other motor vehicles principally } \\
\text { designed for the transport of persons (other } \\
\text { than motor vehicles for the transport of ten or } \\
\text { more persons, including the driver), including } \\
\text { station-wagons and racing cars. }\end{array}$ & 0,76 & 0,45 & 0,34 \\
\hline $\begin{array}{l}\text { Kazakh- } \\
\text { stan }\end{array}$ & 781 & $\begin{array}{l}\text { Motor cars and other motor vehicles principally } \\
\text { designed for the transport of persons (other } \\
\text { than motor vehicles for the transport of ten or } \\
\text { more persons, including the driver), including } \\
\text { station-wagons and racing cars. }\end{array}$ & 0,72 & 0,02 & 0,6 \\
\hline Azerbaijan & 782 & $\begin{array}{l}\text { Motor vehicles for the transport of goods and } \\
\text { special-purpose motor vehicles }\end{array}$ & 0,04 & 0,07 & 0,21 \\
\hline Russia & 782 & $\begin{array}{l}\text { Motor vehicles for the transport of goods and } \\
\text { special-purpose motor vehicles }\end{array}$ & 0,02 & 0,10 & 0,21 \\
\hline Ukraine & 782 & $\begin{array}{l}\text { Motor vehicles for the transport of goods and } \\
\text { special-purpose motor vehicles }\end{array}$ & 0,00 & 0,00 & 0,13 \\
\hline $\begin{array}{l}\text { Kazakh- } \\
\text { stan }\end{array}$ & 782 & $\begin{array}{l}\text { Motor vehicles for the transport of goods and } \\
\text { special-purpose motor vehicles }\end{array}$ & 0,00 & 0,37 & 0,72 \\
\hline Russia & 791 & $\begin{array}{l}\text { Railway vehicles (including hovertrains) and as- } \\
\text { sociated equipment }\end{array}$ & 0,02 & 0,41 & 0 \\
\hline Armenia & 791 & $\begin{array}{l}\text { Railway vehicles (including hovertrains) and as- } \\
\text { sociated equipment }\end{array}$ & 0,40 & 0,27 & 0,53 \\
\hline Ukraine & 791 & $\begin{array}{l}\text { Railway vehicles (including hovertrains) and as- } \\
\text { sociated equipment }\end{array}$ & 0,39 & 0,73 & 0 \\
\hline Ukraine & 792 & $\begin{array}{l}\text { Aircraft and associated equipment; spacecraft } \\
\text { (including satellites) and spacecraft launch ve- } \\
\text { hicles; parts thereof }\end{array}$ & 0,05 & 0,11 & 0,49 \\
\hline
\end{tabular}




\begin{tabular}{|c|c|c|c|c|c|}
\hline Azerbaijan & 842 & $\begin{array}{l}\text { Women's or girls' coats, capes, jackets, suits, } \\
\text { trousers, shorts, shirts, dresses and skirts, un- } \\
\text { derwear, nightwear and similar articles of tex- } \\
\text { tile fabrics, not knitted or crocheted (other } \\
\text { than those of subgroup 845.2) }\end{array}$ & 0,00 & 0,11 & 0,96 \\
\hline Russia & 842 & $\begin{array}{l}\text { Women's or girls' coats, capes, jackets, suits, } \\
\text { trousers, shorts, shirts, dresses and skirts, un- } \\
\text { derwear, nightwear and similar articles of tex- } \\
\text { tile fabrics, not knitted or crocheted (other } \\
\text { than those of subgroup 845.2) }\end{array}$ & 0,38 & 0,27 & 0,89 \\
\hline $\begin{array}{l}\text { Kazakh- } \\
\text { stan }\end{array}$ & 842 & $\begin{array}{l}\text { Women's or girls' coats, capes, jackets, suits, } \\
\text { trousers, shorts, shirts, dresses and skirts, un- } \\
\text { derwear, nightwear and similar articles of tex- } \\
\text { tile fabrics, not knitted or crocheted (other } \\
\text { than those of subgroup 845.2) }\end{array}$ & 0,00 & 0,00 & 0,32 \\
\hline Azerbaijan & 845 & $\begin{array}{c}\text { Articles of apparel, of textile fabrics, whether or } \\
\text { not knitted or crocheted, n.e.s. }\end{array}$ & 0,00 & 0,24 & 0,68 \\
\hline Armenia & 845 & $\begin{array}{c}\text { Articles of apparel, of textile fabrics, whether or } \\
\text { not knitted or crocheted, n.e.s. }\end{array}$ & 0,08 & 0,47 & 0,05 \\
\hline $\begin{array}{l}\text { Kazakh- } \\
\text { stan }\end{array}$ & 845 & $\begin{array}{c}\text { Articles of apparel, of textile fabrics, whether or } \\
\text { not knitted or crocheted, n.e.s. }\end{array}$ & 0,00 & 0,11 & 0 \\
\hline Azerbaijan & 872 & $\begin{array}{l}\text { Instruments and appliances, n.e.s., for medical, } \\
\text { surgical, dental or veterinary purposes }\end{array}$ & 0,81 & 0,12 & 0,01 \\
\hline Russia & 872 & $\begin{array}{l}\text { Instruments and appliances, n.e.s., for medical, } \\
\text { surgical, dental or veterinary purposes }\end{array}$ & 0,00 & 0,25 & 0,67 \\
\hline Armenia & 872 & $\begin{array}{l}\text { Instruments and appliances, n.e.s., for medical, } \\
\text { surgical, dental or veterinary purposes }\end{array}$ & 0,39 & 0,49 & 0,9 \\
\hline
\end{tabular}

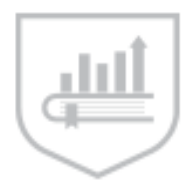

